\title{
Analysis of Russian legislation from the point of view of gender asymmetry
}

\section{Анализ российского законодательства с точки зрения гендерной асимметрии}

\author{
Received: April 3, $2021 \quad$ Accepted: April 25, 2021
}

Written by:

Olga V. Klimashevskaya ${ }^{29}$

https://orcid.org/0000-0003-0056-2495

https://elibrary.ru/author_profile.asp?id=1067349

Pavel E. Studnikov ${ }^{30}$

https://orcid.org/0000-0001-8836-1158

https://www.scopus.com/authid/detail.uri?authorId=57211654889\&amp;eid=2-s2.0-85074744502

https://elibrary.ru/author_profile.asp?id=1023886

Pavel V. Poznyakov ${ }^{31}$

https://orcid.org/0000-0003-1658-6184

https://elibrary.ru/author_profile.asp?id=1026105

\begin{abstract}
This article is devoted to the analysis of Russian legislation from the point of observance of gender symmetry and the identification of norms that infringe on the rights of one of the genders and thereby hinder the exercise of rights on equal footing. The starting point in the research methodology is the study of the concept of a gender-neutral norm, which should proceed from the position of ensuring equality of conditions and opportunities for men and women to the same extent. Also, a gender analysis of Russian legislation was used as a methodology, as a result of which it can be concluded that the Russian state, as an institution to which society has delegated power, is not fully consistent in the political measures and steps taken to resolve this issue. The final conclusion that was reached during the study, in a number of cases, seems advisable to revise the provisions of Russian legislation beforehand with sociological research, which makes it possible to reveal the real effectiveness and possible side negative consequences of the application of certain legal norms and thereby minimize the procedural problems that arise in this regard.
\end{abstract}

Резюме

\begin{abstract}
Данная статья посвящена анализу российского законодательства с позиции соблюдения гендерной симметрии и выявлению норм, которые ущемляют права одного из полов и тем самым препятствуют реализации прав на паритетных началах. Отправной точкой в методологии исследования является изучение понятия гендерно нейтральной нормы, которая должна исходить из позиции обеспечения равенства условий и возможностей для мужчин и женщин в одинаковой степени. Также в качестве методологии использовался гендерный анализ российского законодательства, в результате которого можно сделать вывод, что российское государство как институт, которому общество делегировало власть, не до конца последовательно в принимаемых политических мерах и шагах по урегулированию данного вопроса. Ну и заключительным выводом, к которому удалось прийти в ходе исследования, в ряде случаев представляется целесообразным пересмотр положений российского законодательства предварить социологическими исследованиями, позволяющими вскрыть реальную эффективность и возможные побочные негативные последствия применения тех или иных правовых норм и тем самым минимизировать процессуальные проблемы, которые возникают в этой связи.
\end{abstract}

\footnotetext{
${ }^{29} \mathrm{PhD}$ in Political Sciences, Associate Professor, Moscow Aviation Institute (National Research University), Moscow, Russia.

${ }^{30} \mathrm{PhD}$ in Political Sciences, Associate Professor, Moscow Aviation Institute (National Research University), Moscow, Russia.

${ }^{31}$ Senior Lecturer, Moscow Aviation Institute (National Research University), Moscow, Russia.
} 
Keywords: gender asymmetry, gender symmetry, gender equality, gender analysis, gender approach.

\section{Introduction}

This article is devoted to the analysis of Russian legislation from the point of observance of gender symmetry and the identification of norms that infringe on the rights of one of the genders and thereby hinder the exercise of rights on an equal footing. The starting point is an analysis of the concept of a gender-neutral norm, which should proceed from the position of ensuring equality of conditions and opportunities for men and women to the same extent.

The relevance and complexity of the task faced by the team of authors is a comprehensive analysis of not only the current legislation, but also legislation, which in the future should change from the perspective of observing gender symmetry. The analysis, first of all, was the regulation of the principle of equal rights and opportunities in those branches of legislation where gender asymmetry is most strongly represented, for example, in labor, or where the implementation of the principle is declarative, in particular, it concerns the legislation on elections. The experts also examined the branches of legislation that had previously been studied in a minimal volume from a gender perspective, this is criminal and penal legislation.

Gender symmetry is accumulated in the Constitution, which lays down the principle of equal rights and equal opportunities for two genders. It is especially important for analysis as it allows interpretation of its implementation in industry legislation. Application of the method of gender symmetry allowed the project participants to combine their efforts and develop recommendations for improving legislation.

The right is understood today as an equal measure of freedom of everyone: men and women. It takes into account the biological characteristics of the gender. This is reflected in the legislation, but the right, is still the carrier of the old idea of the role of women in society, although this is not clearly expressed.

There is also the problem of discrimination on the basis of gender, and this is associated with the traditions that are alive in society. This is especially felt in the implementation of legislation. After examining the Russian legislation, it is not balanced everywhere at the
Ключевые слова: гендерная асимметрия, гендерная симметрия, гендерное равенство, гендерный анализ, гендерный подход.

level of the normative standards of two genders. There is an asymmetry in the legislation. To what extent this is justified, time will tell.

\section{Theoretical Basis}

We believe that a gender neutral norm should be understood as a legislative measure, in the text of which there is no consolidation of the advantage of one gender or another in the performance of certain social, political, labor and civic roles in order to prevent gender discrimination and not create the impression that one gender has advantages over the other (Suchland, 2008; Rimashevskaia, 2011). However, "blind" adherence to achieving gender neutrality in Russian legislation can turn out to be a negative side, since physiological characteristics, as well as cultural and mental models of behavior of each of the genders, will not be taken into account. An obligatory element of such an analysis should be "positive discrimination", which for a certain gender turns into "supporting" component (Gradusova, 2011: Chekalina, 2009; Shtyleva, 2001). However, the necessity and effectiveness of securing this component must be justified.

\section{Methodology}

Gender analysis of Russian legislation can be carried out using five parameters.

1) Set of social and political human rights and freedoms enshrined in the Constitution and federal legislation of the Russian Federation. This scope of rights and freedoms of men and women is implemented at the level of state consolidation and free exercise. Human rights and freedoms are recognized as the highest value and fundamental principle of state policy (Barchunova, 2003; Resnyansky \& Amiantova, 2019).

In particular, social human rights as standards are already embedded in the Constitution of the Russian Federation, taking into account the status of a woman and her role as a mother and at the same time the role of a father (Ashwin \& Isupova, 2018; Belinson, 2018). Motherhood and fatherhood are special functions and are anchored through the human rights. However, the Article 38 of the Constitution of Russia 
specifically stipulates that motherhood is under the protection of the state (Constitution of the Russian Federation; 2020), and the Article 7 contains a complete list of subjects to constitutional protection and support: "family, motherhood, fatherhood and childhood".

Is the additional consolidation of the functions of motherhood an indicator of the development of the doctrine of human rights? Should this difference in gender roles be emphasized and enshrined in the Constitution of the Russian Federation?

After all, human rights enshrined in the Constitution of the Russian Federation are designed to reflect the idea of gender symmetry. They should be designed with respect for the principle of equality on the basis of gender and meet the same standards for the two genders from the perspective of motherhood and from the perspective of fatherhood (Kabeeva \& Kalinina, 2018; Busygina \& Shtrikova, 2019).

If we consider the political rights enshrined in the Constitution of 1993, they also, at first glance, do not have gender asymmetry. They fully reflect the concept of gender equality and do not raise any doubts. One of the basic political rights is the right to elect and the right to be elected. These constitutional rights personify the democratic institution of power formation as the main institution of the state. However, during elections, the public questions this right. The confirmation of this is the elections to the State Duma. Only $15.3 \%$ of the votes were cast for women who ran for parliament. Elections are an indicator of the adaptability of the constitutional principle of equality and its separability by society (Semykina \& Linz, 2013; Tarusina \& Isaeva, 2016).

2) Considering women's rights as a separate category of human rights. A separate consideration arose against the background of revealing gender asymmetry in the legal and factual planes of various spheres of life. The established facts of discrimination against women serve as an indicator.

3) Consideration of men's rights as a separate category of human rights, which arose as a response to the "active" provision of equality for women in the spheres of public life. Accordingly, the reproaches that are expressed against legislators and authors of gender studies, in connection with the unjustifiably exaggerated women's topic in them, are largely justified (Zavadskaya, 2001).
4) Definition of measures and indicators of equality: rights, freedoms, duties, responsibilities of each of both genders and possibility of their unhindered implementation in life (Pushkareva \& Bolshakova, 2020).

5) This parameter follows from the fourth, it is equality of opportunity. It reflects the degree of thoughtfulness of state policy at the legislative level in relation to the implementation of men and women, the level of guarantees provided, as well as the creation of an enabling environment that will favor the implementation of equality indicators (Turbine \& Riach, 2012).

The parameters from the second to the fifth are specific and, at a meaningful level, can help in understanding the principle of observance of gender symmetry in its legislative dimension and in practice (Dugarova, 2019).

\section{Results and Discussion}

Turning to Russian legislation, the following gender-asymmetric laws in the labor sphere were identified. According to the Article 64 of the Labor Code of the Russian Federation "It is forbidden to refuse to conclude an employment contract for women for reasons related to pregnancy or the presence of children" (Law No 197-FZ, 2001a). This measure protects the rights of women to maternity and does not allow discrimination in employment situations. However, it is unlikely that a refusal to the applicant will be formally and documented for the reason specified in the Article 64. Not only general human moral principles operate, but also the unwillingness of employers to come into conflict with the letter of the law. In the labor sphere, to a greater extent, there is an aggravating factor for women, such as having a family and children, when hiring. However, it exists by default and never appears in official refusals when applying for a job (Sillaste, 2000; Pushkareva \& Zolotukhina, 2018).

Further, it is interesting to consider the Article 70 of the Labor Code of the Russian Federation "Test for employment is not established for pregnant women and women with children under the age of one year and one and a half years" (Law No 197-FZ, 2001b). The considered norm also protects the interests of young mothers or women who are going to soon experience the happiness of motherhood. However, there is a problem for this category of female representatives before concluding a contract for a probationary period, namely, to receive a 
positive decision from the management about hiring. The factors of having a small child or pregnancy are often not perceived by employers as positive criteria. The task of a merchant, as a rule, is to make a profit and increase income from the activities of the organization, therefore, the presence of the above factors hardly seem promising in terms of the labor contribution of the accepted employee to the development of the organization (Repina, 2006).

Thus, the Article 64 and 70, on the one hand, protect the position of women when hiring, guarantee them the inviolability of motherhood, and on the other hand, there is a clear understanding of the "formality" of the presence and ineffectiveness of the application of these norms of the Labor Code of the Russian Federation in practice. These norms do not at all take into account the similar position of fathers when hiring. There are a sufficient number of examples when a man alone has to raise a young child still under the age of 1.5 years old. However, these categories of single-parent families do not even have such legal protection in the form of the above considered norms of labor legislation.

Article 83 of the Labor Code of the Russian Federation is interesting for analyzing the position of men of conscription age in the labor sphere. It states that "employment contract is subject to termination for the following circumstances, beyond the control of the parties: call of employee for military service or sending him to an alternative civilian service that replaces it" (Law No 197-FZ, 2001c).

Thus, for men, leave in connection with conscription for military service is not provided for by law, and, accordingly, a job in this situation is not retained for him. A pregnant woman and a woman who has given birth to a child, in most situations is not able to perform the work assigned to her, but at the same time has the right to maternity leave to care for a child, that is, retaining a job. It should be noted that the passage of a man's military service on conscription, as well as caring for a child by a woman, is included in the insurance experience taken into account when calculating the insurance pension. However, labor legislation sees the legal regulation of these situations differently (Zdravomyslova, 2016).

There are also examples of articles from the labor code that are interesting from the point of view of analyzing gender-asymmetric legislation:
Article 96 and 99, which regulate the work of female representatives at night and list the factors that prevent them from performing overtime work. Thus, a positive assessment is formed when familiarizing with the text of documents, where motherhood and the health of workers are put in priority.

As it turned out, there are a huge number of such norms that mention the category of "woman" in the text of a legal document in the absence of the category "man" in the same article. They specify restrictive measures on the use of women's labor in hard work and prohibiting measures related to the use of women's labor in connection with hazardous working conditions (Article 253); situations of transfer to another job of pregnant women and those with children under the age of one and one and a half years old are regulated (Article 254); considered the legal possibilities during the period of parental leave (Article 256); guarantees of women with children under three years old upon termination of an employment contract are indicated (Article 261).

In the norms of labor legislation, we can also learn about the possibility of providing women working in rural areas with an additional day off per month (Article 262); about the possibility of getting additional leave, however, without preserving wages for up to 14 calendar days, regardless of whether she is raising a child alone or with father. For the father of the child, such an opportunity is provided only in the case when he is the only parent (Article 263). It also provides an opportunity to familiarize yourself with information on guarantees and benefits provided in connection with motherhood (Article 264) of the Labor Code of the Russian Federation. For fathers who are divorced and raising children, guarantees and benefits are not provided, only in the event of the loss or death of the mother.

Mothers receive guarantees and benefits in any case.

Well, in conclusion, there is the Article 320, which establishes a 36-hour working week for women working in the Far North and equivalent areas. At the same time, wages are paid in the same amount as for a full working week.

The analysis of labor legislation was carried out in order to understand the extent to which the rights of women-mothers and men-fathers in the labor sphere are protected, to what extent the norms have the possibility of their practical implementation and not the formalities of 
existence, as well as providing real guarantees for the category in need population regardless of gender. Not all of the norms under consideration equally regulate the position of women-mothers and men-fathers in similar life situations. Fathers in similar situations find it more difficult from a legal point of view, since they need additional vitality and costs in order to prove their right to equally use the provided state guarantees as parents of minor children. In most cases, this has to be decided through court decisions, which may not always be in favor of the male parent, due to the fact that the existing norms do not regulate the legal status of fathers.

Further, the study of federal laws "On military duty and military service" and "On the status of military personnel", as well as military regulations, became curious. For review were taken the Articles 8, 13, 15, 22, 34, 38, 50, 55 of the first of these laws, the Article 11, part 13 of the second law and the text of the charter. They define the following principles:

- only men are subject to military registration, with some certain exceptions, and only those who have a military registration specialty are subject to it;

- compulsory training in the basics of military service and in military registration specialties is meant only for men; male citizens between the ages of 18 and 27 are subject to conscription;

- women can enter contract service without being in the reserve, without graduating from special educational institutions and without going through conscription service. A man applying for a contract is required to fulfill one of these conditions;

- soldier must be excluded from the lists of the military unit's personnel on the day of the expiration of his military service, except for cases when a female soldier is on maternity leave. Parental leave is only granted to female military personnel. A male soldier, even theoretically, does not have the right to this type of leave, despite any existing life situations;

- female citizens are exempt from military fees.

Having examined the principles of conscription, one recalls the Article 20 of the Constitution of Russia, "which guarantees every citizen of the country the right to life" (Constitution of the Russian Federation, 2020) and Article 56, paragraph 3 states that "rights and freedoms provided for in the Article 20 are not subject to restrictions" (Constitution of the Russian Federation, 2020).

Thus, we can conclude that the state has the right to dispose of the health, life and fate of men, rather than women at its own discretion. First of all, we are talking about the forced recruitment into the army or the unhindered direction of men to places that pose an immediate threat to his life (meaning "hot spots" where there are armed conflicts of varying intensity). Also, based on the texts of the articles, the state is empowered to impose more stringent conditions and requirements for men when entering contract service. The above legal foundations are supported by lines from the military regulations: "Soldier is obliged: to be faithful to the Military oath, to serve his people selflessly, to defend the Russian Federation, to fulfill his military duty, to endure the difficulties of military service courageously, skillfully, not sparing his blood and life itself".

Further, from the point of view of gender asymmetry, the pension legislation came under consideration, which states that obtaining the right to a pension for males occurs with a greater length of service and at an older age. The difference in the retirement age of men and women of five years was determined back in the 1930s and remained after the pension reform carried out in 2019.

Experts from the All-Russian Scientific Research Institute of Labor explained why the retirement age for men upon retirement due to old age is higher than for women. In establishing the time difference in retirement, the additional burden placed on women in relation to their role in raising children and maintaining the economy was taken into account. These arguments were further confirmed in 2000 by the Constitutional Court of the Russian Federation, which indicated that the difference was justified by an orientation towards physiological differences between the genders and the state policy of protecting the rights of motherhood. However, according to a study conducted in February 2020, more than $40 \%$ of men called it discrimination to retire five years later than women and $28 \%$ of female respondents supported them. The study involved 1.6 thousand citizens of both genders over 18 years old, living throughout Russia. Male respondents substantiated their position, referred to the statistics of life expectancy and health status at the turn of the retirement age.

The Law "On the Police" is interesting in the context of the topic under consideration by the 
Article 23, which states that in relation to women the use of firearms with shots to kill is restricted more severely than in relation to men, to whom the use of firearms is allowed not only in cases of armed resistance, the commission of an armed or group attack threatening the life and health of citizens or a police officer" and in more humane situations.

The Code of Administrative Offenses has also come to the spotlight as an example of genderasymmetric legislation with its Articles 3.9 and 4.2. According to the text of the first of these, "women with children under 14 years old are not a subject to administrative arrest. There is no such privilege for fathers of children under 14 years old" (Law No 195-FZ, 2001a).

The second article concretizes that "as circumstances mitigating administrative responsibility, it is recognized, among other things, the commission of an administrative offense by a woman who has a young child. For fathers of young children, this mitigating circumstance is not provided" (Law No 195-FZ, 2001b).

In the Criminal Code of the Russian Federation, it was possible to find a greater number of examples in which unequal legal regulation of situations in terms of gender is specified. Thus, the Article 78 regulates "that convicted men serving sentences in a colony (this is a milder regime than a prison) can be transferred to prison (more strict regime) for persistent violations of order, and women who are also serving sentences in a colony cannot be transferred to prison (that is, to receive a tightening of the regime) for any violations" (Law No 63-FZ, 1996a). The Article 90 states that "women can receive transmissions without limitation in quantity and for men the number is limited" (Law No 63-FZ, 1996b). The Article 97 states that "convicted women who have minor children with disabilities outside the correctional colony are allowed one short-term trip a year to visit them for up to fifteen days, not counting the roads" (Law No 63-FZ, 1996c). This is not provided for men with minor children with disabilities. The Article 99 concerns the normative minimum of living space: for men in colonies - 2 square meters; for women - at least 3 square meters. The Articles 115, 132, 177 can also be stated as a lightened type of punishment for female representatives, associated with the provision of a delay in serving the sentence by the mother until the child reaches the age of fourteen. Fathers of children under 14 years old do not have this benefit.

\section{Conclusions}

Based on the analysis of legislation of the Russian Federation, there are the following conclusions:

1. State as an institution to which society has delegated power is not completely consistent. It proclaims the principle of equality and at the same time ignores it, failing to ensure its observance in life. This is in conditions when society has not yet developed a culture of respect for the principle of equality, although it is being brought up on new standards of human rights, one of which is the standard of respect for a person in his gender dimension. It is confirmed by the analysis of Russian legislation in the above areas.

2. Legal measures to ensure gender equality should be procedural in nature. This is due to the fact that the legal norm, material in its essence ("man and woman have equal rights") does not work in society. This is due to the fact that substantive law always needs support. It does not work where there is a question of ambiguity in its implementation. Procedural norms (procedures) are not only a mechanism for translating substantive law into real social relations, into practice, but also a process of ensuring equality in rights. If the norm of Russian legislation in any of the areas under consideration contains a standard of equal rights, they should be provided with equal opportunities (i.e., process and procedures), which act as norms of support for equal rights. Therefore, when it comes to the preparation of a draft law on equal rights and opportunities for men and women, it is clear that the nature of the law should be strictly procedural.

3. Presence of gender asymmetry in almost all areas of legislation that are unstable from the point of view of formal or de facto equality of the genders indicates an insufficiently consistent gender approach. The reasons for this lie in the well-known "automatism" of our perception of the issue of masculinity and femininity, which is traditionally considered solved in Russia and does not cause any serious problems. To a certain extent, under the influence of this stereotype of achieved equality, most of the specialists involved in the development of legal norms of codes, as well as federal laws, were apparently also, which led to some "distortions" in the legal regulation of relations between men and women. 
4. In a number of cases, it seems advisable to preface the revision of the provisions of Russian legislation with sociological studies that reveal the real effectiveness and possible side negative consequences of the application of certain legal norms and thereby minimize the procedural problems that arise in this regard.

\section{References}

Ashwin, S., \& Isupova, O. (2018). Anatomy of a stalled revolution: Processes of reproduction and change in Russian women's gender ideologies. Gender \& Society, 32(4), 441-468.

Barchunova, T. V. (2003). The selfish gender, or the reproduction of gender asymmetry in gender studies. Studies in East European Thought, 55(1), 3-25.

Belinson, O. (2018). Female rule in imperial Russia: Is gender a useful category of historical analysis? A Companion to Global Queenship, 79-93.

Busygina, A. L., \& Shtrikova, D. B. (2019). Unlocking the female employment potential: gender aspect. European Proceedings of Social and Behavioural Sciences, 57, 1042-1054. Doi: 10.15405/epsbs.2019.03.104. Available: https://www.europeanproceedings.com/files/dat a/article/101/4703/article_101_4703_pdf_100.p df

Chekalina, A. A. (2009). Gender Psychology. Moscow: Os'. Available: https://core.ac.uk/download/pdf/268005061.pdf Constitution of the Russian Federation (2020). Constitution of the Russian Federation with all the latest amendments. Moscow: AST.

Dugarova, E. (2019). Gender, work, and childcare in Kazakhstan, Mongolia, and Russia. Social Policy \& Administration, 53(3), 385-400.

Gradusova, L. V. (2011). Gender pedagogy. Moscow: Science. Available: https://rucont.ru/file.ashx?guid=8b644615b57e-4fad-a842-a15eb97d7a99

Kabeeva, N., \& Kalinina, A. (2018). State policy formation vectors in gender discrimination countering actions in Russia. European Proceedings of Social and Behavioural Sciences, 35, 511-519.

Law No 195-FZ (2001a). Article 3.9. Administrative arrest. In "Code of the Russian Federation on Administrative Offenses" of 30.12.2001 N 195-FZ. Moscow: Federal Assembly. Ed. of 24 february, 2021. Available: http://www.consultant.ru/document/cons_doc_L AW_34661/44743d8648cb45df9055b2b9a43ed c176c5fc0d4/
Law No 195-FZ (2001b). Article 4.2. Circumstances mitigating administrative responsibility. In "Code of the Russian Federation on Administrative Offenses" of 30.12.2001 N 195-FZ. Moscow: Federal Assembly. Ed. of 24 february, 2021. Available: http://www.consultant.ru/document/cons_doc_L AW_34661/6210e4a746ad4504c7d8f79309a46 3f3d7d35961/

Law No 197-FZ (2001a). Article 64. Guarantees when concluding an employment contract. In "Labor Code of the Russian Federation" of 30.12.2001 N 197-FZ. Moscow: Federal Assembly. Ed. of 29 december, 2020. Available: http://www.consultant.ru/document/cons_doc_L AW_34683/f9ccec223c774c4895b03311bcd7eb 355ef9d78f/

Law No 197-FZ (2001b). Article 70. Test for hiring. In "Labor Code of the Russian Federation" of 30.12.2001 N 197-FZ. Moscow: Federal Assembly. Ed. of 29 december, 2020. Available:

http://www.consultant.ru/document/cons_doc_L AW_34683/cc065f088bd92d312b5fae714377b2 $5 \mathrm{f} 557 \mathrm{ac} 44 \mathrm{a} /$

Law No 197-FZ (2001c). Article 83. Termination of an employment contract due to circumstances beyond the control of the parties. In "Labor Code of the Russian Federation" of 30.12.2001 N 197FZ. Moscow: Federal Assembly. Ed. of 29 december, 2020). Available: http://www.consultant.ru/document/cons_doc_L AW_34683/3cada1c48e0ead0990c871576b4bc7 dc1ff19ab1/

Law No 63-FZ (1996a). Article 78. In Criminal Code of the Russian Federation. Moscow: Federal Assembly, June 13, 1996.

Law No 63-FZ (1996b). Article 90. In Criminal Code of the Russian Federation. Moscow: Federal Assembly, June 13, 1996.

Law No 63-FZ (1996c). Article 97. In Criminal Code of the Russian Federation. Moscow: Federal Assembly, June 13, 1996.

Pushkareva, N. L., \& Bolshakova, O. V. (2020). Gender Studies of the Russian Twentieth Century. Saint Petersburg University Bulletin History, 65(1), 318-328.

Pushkareva, N., \& Zolotukhina, M. (2018). Women's and Gender Studies of the Russian Past: two contemporary trends. Women's History review, 27(1), 71-87.

Repina, L. (2006). Gender Studies in Russian Historiography in the nineteen-nineties and early twenty-first century. Historical Research, 79(204), 270-286.

Resnyansky, S. I., \& Amiantova, I. S. (2019). Gender in Russian history: review of the latest researches. RUDN Journal of Russian History, 18(2), 278-301. 
Rimashevskaia, N. M. (2011). Gender asymmetries in today's Russia. Russian Education \& Society, 53(10), 3-22.

Semykina, A., \& Linz, S. J. (2013). Job satisfaction and perceived gender equality in advanced promotion opportunities: An empirical investigation. Kyklos, 66(4), 591-619.

Shtyleva, L. V. (2001). Gender Approach in Preschool Pedagogy: Theory and Practice. Murmansk: Kola Regional Center for Continuing Education and Development of Women.

Sillaste, G. G. (2000). Gender sociology as a special sociological theory. Sociological research, 11, 5 .

Suchland, J. (2008). Contextualizing discrimination: The problem with sexual harassment in Russia. Journal of Women, Politics \& Policy, 29(3), 335-363.

Tarusina, N., \& Isaeva, E. (2016). Equalization of Legal Status with Respect to Gender. Russian Law Journal, 4(3), 74-93.

Turbine, V., \& Riach, K. (2012). The right to choose or choosing what's right? Women's conceptualizations of work and life choices in contemporary Russia. Gender, Work \& Organization, 19(2), 165-187.

Zavadskaya, L. N. (2001). Gender expertise of Russian legislation. Moscow: BEK.

Zdravomyslova, O. (2016). "Gender and Power": Reading Raewyn Connell in Russia. Sociological Review, 15(3), 213-222. 